\title{
Skating with Donovan: Thoughts on Librarianship As a Profession
}

\author{
Richard A. Danner
}

\begin{abstract}
James M. Donovan's article: "Skating on Thin Intermediation: Can Libraries Survive?" argues that librarians place more emphasis than they might on providing service to library users at a time when information seekers are relying less on intermediaries, and that over-emphasizing service to the detriment of other values diminishes the status of librarianship as a profession. The article presents two contrasting models of librarianship. This article discusses Donovan's models and comments on the continuing importance of the service model to librarianship.
\end{abstract}

KEYWORDS. Professions, librarianship, law librarianship

\section{INTRODUCTION}

My favorite professor at the University of Wisconsin Library School (now School of Library and Information Studies) was Jack Alden Clarke, who taught at the school from 1965 until he retired in 1986. Professor Clarke taught his social sciences reference course by thumbing through thick dog-eared manila folders filled with ads for reference sources that he had collected (perhaps to update his text: Research Materials in the Social Sciences $^{1}$ ), and wanted to talk about that day in class. I remember him (others' recollections may differ) as being a bit wild-eyed as he whipped

Richard A. Danner is Rufty Research Professor of Law and Senior Associate Dean for Information Services, Duke Law School, Durham, NC (E-mail: zad@law.duke.edu).

The author wishes to thank Katherine Topulos for her research assistance on this article.

Legal Reference Services Quarterly, Vol. 27(2-3) 2008

Available online at http://www.haworthpress.com

(C) 2008 by Richard A. Danner

doi: 10.1080/02703190802409008 
through his folders and notes, seemingly putting together each class on the fly, somehow giving the impression that he was always really thinking about something else.

One day, perhaps in the middle of a discussion on the value of the then still fairly new International Encyclopedia of the Social Sciences (1968), Professor Clarke paused for a moment, looked out at the class, and said: "You know, there is no point in doing any of this unless you stop sometimes and think about what it is you're doing. You shouldn't be doing any job unless you know why you are doing it." And then, he turned back to his folders to continue with whatever was the topic of the day.

Initially, Clarke's comment struck me mostly because of its timing, but it has stayed with me. When I heard it, as I was about to begin my career, librarianship itself was on the verge of an era in which "thinking about what you are doing" would become a necessary exercise for practicing librarians. An era in which telling a new acquaintance that you are a librarian leads not necessarily to a bemused smile and comments about getting to read the new books first, but to questions about why, anymore, do we need librarians or even libraries at all.

\section{“SKATING ON THIN INTERMEDIATION”}

James M. Donovan's article: "Skating on Thin Intermediation: Can Libraries Survive?"2 is a welcome contribution to conversations that librarians are and should be having among themselves and with others in journals, blogs, and other forums. ${ }^{3}$ In that spirit, I appreciate the opportunity to comment on Mr. Donovan's article.

Donovan is concerned about what he perceives as the tendency of librarians to place more emphasis than they might on their role in providing service to library users at a time when information seekers see less and less need to rely on intermediaries to find the information they need. Among others, he then cites Harvard Law Librarian Terry Martin for his suggestion at a 1996 American Association of Law Libraries town meeting that the need for librarian intermediation between information seeker and information sought has always been "a systems failure to some degree,"4 stemming from librarians' long-standing poor training of their users, poorly designed catalogs, and poor organization of collections. (Ah, Terry, the things we'll say while being cross-examined by Arthur Miller.) Donovan also quotes Martin for his comment later on in the town meeting: "I don't care if books are gone. In fact, from my point of view, it would be good if books were 
gone. ..." $" 5$ The quotation in Donovan's article, however, does not complete Martin's comment, which describes his allergies to the dust and mold in books as the reason why "it would be good if books are gone."

Donovan's concern with intermediation is actually less with librarians' staking their future on a role they might lose than with the impacts of their emphasis on service on the status of librarianship as a profession. After his initial comments on intermediation, he moves to the heart of his article: a discussion of two contrasting models of librarianship. That discussion includes critiques of two works that focus on law librarianship as a profession. One is the 1996 report of the AALL Special Committee on the Renaissance of Law Librarianship in the Information Age; ${ }^{6}$, the other is my 1998 Law Library Journal article: "Redefining a Profession." Donovan closes his article with thoughts on librarianship as a profession. I will comment here on the models proposed by Donovan and the questions he poses about the service mission of librarianship. ${ }^{8}$

\section{MODELS OF LIBRARIANSHIP}

Donovan finds a threat to libraries and to librarians ${ }^{9}$ in the ways that librarians have reacted to technology, or as he puts it "more precisely, librarians' reactions to how technology has changed patron expectations." 10 He presents two models of librarianship to explain librarians' responses to the changing demands of library patrons: one is described as a "weak" model, in which the librarian's primary role is to react to institutional pressures and patron demands by striving to provide "something called "good service" "to library users; the other is a "strong" model, which emphasizes adherence to professional values and ideals "while pragmatically answering to bureaucrats and striving to foster a positive experience for patrons." 11 (Donovan notes that calling the service-based model "weak" is not meant to be pejorative, yet one wonders why he chose the labels "weak" and "strong" for his models when other (perhaps more descriptive) labels, e.g., "service" or "user-oriented" for the first, and "values" or "professional" for the second, might have been used.)

Donovan sees what librarians do under the service-based weak model as externally defined and possibly disconnected from professional values and the essential tasks of libraries. ${ }^{12}$ The strong model, however, incorporates not only service to patrons, but "other, sometimes conflicting responsibilities," tied closely to professional values. ${ }^{13}$ For Donovan: 
Which model one follows mirrors one's stance on the question of whether librarianship is a true profession. Without a firm commitment to the profession-based strong model, librarians are destined to fade into oblivion along with other old-fashioned "good service" providers like the milkman, travel agent, and the local shopkeeper. ... ${ }^{14}$

For Donovan, because it emphasizes meeting users' information needs, the weak model lacks connection to the values and ideals that are necessary for an occupation to be a profession, not merely a job. He finds a postmodernist foundation for the weak model in sources such as Laura Cohen's "A Librarian's 2.0 Manifesto,"15 a list of rather innocuous "affirmations" such as: "I will recognize that the universe of information culture is changing fast and that libraries need to respond positively to these changes to provide resources and services that users need and want." Cohen intends her 17 statements "to generate positive energy as [librarians] engage with some of the pressing challenges that face the profession," 16 and to create traction for her hopes to incorporate the culture of Web 2.0 ("the revolution in the way people create, edit, search, evaluate, organize, and share information" ${ }^{17}$ ) into libraries ("Library 2.0"). Cohen's affirmations emphasize the need for librarians to learn the "information culture" of their users and to shape [library] services to reflect users' preferences and expectations." 18 Donovan argues that, because they are influenced by popular culture, the demands of library users "have grown at odds with the long-term responsibilities of librarians, and librarians seem unable to resist being pulled along." ${ }^{19}$ As evidence, he cites libraries emulating Google's search engine in their online catalogs, the Library of Congress wishing to "dumb down" its cataloging practices, and products like Google Book Search effectively encouraging their users "to think in digestible, keyword-accessible bytes at the expense of complex ideas." 20 As Donovan points out, "nowhere does [Cohen] mention heretofore traditional skills such as collection development, evaluation, or preservation." 21

Cohen's manifesto and other sources Donovan cites might exemplify postmodernist librarian responses to changes in technology by emphasizing engagement with library users and employment of new technologies, but are they necessarily at odds with appropriate professional values for librarians? At least some "postmodern" commentary on libraries and librarianship is helpful in thinking about these questions. Donovan quotes a 1999 article by Dave Muddiman primarily for its description of a usercentered postmodern library, ${ }^{22}$ but, read in its entirety, Muddiman's piece 
also provides a fascinating take on the history and development of the modern library.

Muddiman argues that, as part of the development of modern societies in Europe and North America, libraries "helped legitimize and control an accepted body of 'public' knowledge which formed a recorded narrative of civilization's progress and the basis for its further advance." ${ }^{23}$ Civil society required free circulation and dissemination of knowledge, as well as literate citizens. As a result, libraries were central institutions in the development of a "public sphere" of discourse, which required what Muddiman terms "a relatively autonomous set of communications networks and social spaces controlled by neither the state nor other vested interests." ${ }^{24}$ In this role, one can see the origins of the values and ideals of modern librarianship, as well as their connections to the traditional functions of the library:

If the modern library was to become the guarantor of access to public knowledge, modern librarianship was equally to develop as a philosophy and practice of its collection, legitimization, organization, and dissemination.... Thus librarianship constructed its ideals, which focused on the unity of learning and the notion that all knowledge can be classified (ordered, disciplined), according to fundamental rules of properties. Librarianship at its most intellectual developed elaborate and sometimes elegant schemes for this process. .. ${ }^{25}$

Eventually, in the twentieth century, Jesse Shera and others would fashion from these elements a view of the library as "a dynamic social institution whose function is both to organize and disseminate knowledge ... to facilitate progressive social change. $" 26$

Muddiman thus demonstrates a useful connection between the traditional activities of libraries and the development of the modern values of the profession of librarianship. He goes on to describe postmodernist critiques of librarianship, which challenge the "modern" view, finding that the discipline of information and library science can also be seen as "a discourse of control rather than of liberation," and that, "despite its occasional idealist rhetoric, librarianship in reality was often mundane, pragmatic, and bureaucratic." ${ }^{27}$ By the end of the twentieth century, scholarship in library and information science turned from concerns with knowledge to focus on information: “ 'Information' is quantified for what it can do, rather than valued, as knowledge, for what it is. The structures of this knowledge themselves, erected so assiduously by 'modern' librarians, become 
mutable, subjective, transient." ${ }^{28}$ Some writers, however, have focused their work on

the potential of information and communication technologies for the liberation of individuals constrained and excluded by the structures and norms of modernity. For these writers, a postmodern ILS is user centered. It must recognize the sovereignty of individuals or communities in the knowledge utilization process and develop theories and (more practically) systems and services to assist them. ${ }^{29}$

As a result, whether or not they think of themselves as postmodernists, many writers about librarianship write less about traditional library activities and are, instead, advocates of the user-centered approach which troubles Donovan.

More recently, Nicholas Joint, inspired by conference discussions at the University of Loughborough in 2006, set out the challenges that librarians face in answering the sorts of questions postmodernists might pose. ${ }^{30}$ Joint notes first the features of the current "largely hybrid information environment":

- Regardless of format, information objects (books, journals, web pages, pdfs) do exist.

- They are describable.

- They are collectable and must be put into ordered collections.

- They are preservable and need to be preserved to maintain the continuity of knowledge.

- These features make the library accessible. ${ }^{31}$

In this hybrid environment (the seemingly unending period of "change" and "transition" to which librarians frequently refer), digital libraries exist, but are in many ways "merely reincarnations of old media, repressing the intrinsic nature of new digital media in order to make change manageable." 32 For some, "the most interesting aspects of any new technology are the aspects which are dissimilar from what went before," but librarians and other creators of "interim digital libraries" often fail to recognize that digital information is not the same as print-despite the attraction initially of pretending that it is. ${ }^{33}$

In contrast to the present interim environment, Joint posits, then explicates, five features of what he calls "a new digital order": 
1. There are no traditional information objects on the internet with determinate formats or determinate qualities: the only information object and information format on the internet is "ephemera."

2. The only map of the internet is the internet itself, it cannot be described.

3. A hypertext collection cannot be selectively collected because each information object is infinite and infinity cannot be contained.

4. The problem of digital preservation is like climate change: it is manmade and irreversible, and means that much digital data is ephemeral; but unlike climate change, it is not necessarily catastrophic.

5. Thus, there is no such thing as a traditional library in a postmodern world. Postmodern information sets are just as accessible as traditional libraries, but without possessing any of the traditional features of a library: there are no formats, no descriptions, no hope of collection management, no realistic possibility of preservation. And they work fine. ${ }^{34}$

Joint asks where librarianship fits into this new digital order, but offers no real answers, perhaps because he finds that the outlines of postmodern cultural forms are still indistinct. ${ }^{35}$ His only advice is that it would be foolhardy for librarians to "charge off in pursuit of revolutionary new visions of professional practice," 36 leaving unanswered questions about the effects on the professional values of librarianship of an environment where the traditional activities of the profession are diminished significantly.

Donovan links his strong model, the basis for librarianship's claim to professional status, variously to librarians' "ethical allegiance ... with values and ideals" 37 ; "an ineliminable core of commitment to ends other than the satisfaction of immediate users" 38 ; a commitment to "higher ends such as bringing context to all information" ${ }^{39}$; and "professional obligations to construct socially useful institutions of cultural knowledge." ${ }^{40}$ For Donovan, the values promoted by the strong model seem to be rooted in the traditional "essential tasks" of libraries as described by Walt Crawford and Michael Gorman: "Libraries exist to acquire, give access to, and safeguard carriers of knowledge and information in all forms and to provide instruction and assistance in the use of the collections to which their users have access." $" 41$

From Donovan's perspective, these roles of the library create the librarian's "independent obligations toward collection development and the organization and preservation of knowledge and information in all its forms," commitments that "extend beyond immediate patron services, 
distinguishing the weak from the strong model." 42 Further, "It is commitment to these higher ends-ends that are not reducible to patron services or satisfactions alone - that elevates librarianship to the status of a profession, and which forms the core of the strong model." 43 Thus, echoing Ranganathan's Laws of Library Science,${ }^{44}$ Donovan also sets out "the librarian's core functions [as] to acquire the right books, to make them accessible, and to assure their continued availability," 45 and states that collection development is "perhaps the cardinal function of the library." 46

In the conclusion to his article, Joint suggests that "the purist notion of a new form of culture, based on internet-based digital technologies, and quite different from what has preceded it, is a powerful one, with important lessons for the way information professionals understand their present and future roles." ${ }^{47}$ It is not necessary to adopt a postmodernist perspective on the future of the library to recognize that the direction of movement within the "hybrid information environment" is toward the alldigital information future he sketches. Whether that future is reached soon or ever, it would seem risky for librarians to bet their futures primarily on the continued primacy of their traditional roles in collection development, and the organization and preservation of knowledge and information, or their professional standing on values based in those roles. At a time when increasing amounts of the information that library users need is supplied electronically by remote providers via the Internet, it seems that even adding digital information to the mix of what is collected, organized, and preserved offers only limited security. But what does the digital future offer librarians to replace the traditional professional values, which seem now to be closely tied to activities (selecting, organizing, and preserving knowledge and information) that might no longer be as essential to the librarian's work in the new digital environment as they were in the past?

\section{WHAT FUTURE FOR SERVICE?}

In the present information environment, Donovan laments the deprofessionalizing effects of librarianship's lack of connection to values, arguing that the weak, "user-dominated" model of librarianship does not provide a solid-enough basis for thinking of librarianship as a profession: "If librarianship is a profession, then the weak model's service ideal is precluded; if, on the other hand, user satisfaction is the librarian's highest good, then librarianship can never be a profession." 48 
In describing his models, Donovan relies, in part, on two sources that focus on law librarianship and suggests that each encourages the weak, service-based model which he believes cannot support the idea of librarianship as a profession. One is the 1996 report of the AALL Special Committee on the Renaissance of Law Librarianship in the Information Age (often referred to as the Renaissance Committee), which was published in 1997 (with supplementary materials) under the title: Toward a Renaissance in Law Librarianship. ${ }^{49}$ As a member of the Renaissance Committee, I co-edited the final report, which was drafted by Peter Schanck (then of the University of Kansas), prepared the report and other materials for publication, and contributed a short paper commenting on an essay by Schanck regarding the future of academic law librarianship. When presented to the AALL executive board, the Renaissance Committee report included a number of recommendations for action by the Association. The AALL board chose to endorse neither the report nor its recommendations, but "accepted" them as the basis for further discussion among the AALL membership. ${ }^{50}$ Donovan also references the Law Library Journal article I published in 1998 under the title: "Redefining a Profession." ${ }^{51}$ Both the AALL report and my later article were written to consider the impacts of technological change on the future of law librarianship as the profession entered a new century.

\section{The Renaissance Committee Report and Recommendations}

The Renaissance Committee was established by AALL President Carol Billings in response to a call in the 1994-1998 AALL strategic plan for the association to "provide leadership to shape the legal information environment in a time of rapid technological and public policy changes." 52 The committee's final report described an environment in which economic, social, and (primarily) technological changes were significantly affecting both the day-to-day work and the core values of law librarians.

In attempting to position law librarianship for a leadership role in the churning information environment that it described, the report emphasized that the mission of the profession should be to "serv[e] the information needs of the legal profession and the legal information needs of the public," noting that the other things librarians do: "acquiring, collecting, organizing, retrieving, and disseminating legal and related information are only subsets of that basic mission." 53 In distinguishing the service mission of law librarians from the other roles of libraries and librarians, this is a significant statement. Certainly, it might be read to support Donovan's claim that 
the Renaissance Committee over-emphasized the librarian's role as service provider to the detriment of other activities that he links to professional values.

But, it is important to recognize that the Renaissance Committee grounded its emphasis on law librarianship's service mission in "a set of essential values or principles" and specifically reminded its readers that "belief in the value of what one does and who one serves is a precondition to doing one's work most effectively." 54 The values listed by the Renaissance Committee focus on access to legal information, belief in the rule of law, opposition to censorship, and commitment to diversity. Thus, in contrast to Donovan's suggestion that too great an emphasis on service decouples librarianship from its other core values, the Renaissance Committee report sought to link law librarianship's mission of service, not only to other functions of the library, but to broader professional values tied to the library's role in society: values not unlike those pointed out by Muddiman in his discussion of the development of the modern library or those implicit in his description of postmodernist writings on the role of the library.

Although Donovan doesn't discuss the Renaissance Committee's statement of professional mission and values for law librarians, he does criticize the report's recommendation that AALL "open its membership to all people, with the same rights of voting and office," his claim that the Renaissance Committee fostered the weak model that he feels de-professionalizes librarianship. For Donovan, the proposal to eliminate educational requirements for membership in AALL "suggests an insecurity about the identity of librarianship itself." 56

I think that most members of the Renaissance Committee would be surprised at this interpretation of their work and recommendation. The open membership proposal was drafted in recognition of the growing numbers of information technologists working in law schools, law firms, and other organizations dealing with legal information. The committee's idea was to encourage legal information technologists to become involved in AALL and acculturated to AALL's values - rather than build another association for legal information technology specialists only, and to position AALL to lead the development of a more inclusive legal information profession "from the position of strength among the information professions that librarianship's established base of knowledge, skills, and values should provide." 57

(Donovan reports that the AALL membership "prudently spurned these short-sighted suggestions at its next annual meeting." 58 Although the Renaissance Committee's open membership proposal was voted down in 
1997, two years later the AALL membership approved a mail ballot amendment to the AALL bylaws, ${ }^{59}$ opening active membership to "any person who is interested in the objectives of the association and works with legal information in a library or information center or provides library services on an independent contract basis." The open membership language remains in AALL's current bylaws. ${ }^{60}$ )

\section{“Redefining a Profession"}

The article "Redefining a Profession" was part of a larger project to explore the impacts of information technologies on legal education and law libraries ${ }^{61}$ Like other members of the AALL Renaissance Committee, I was intrigued by the growing numbers of information technologists being hired in legal organizations, and wondered about the implications for law librarians. If legal information was increasingly accessible on the desktops of law professors, students, lawyers, judges, and others via Lexis, Westlaw, and other databases (let alone the then only nascent possibilities of the Internet and World Wide Web) through networks and terminals provided and serviced by technologists, how would the role of the librarian change? In working with lawyers and others to improve access to legal information, technologists were beginning to do some of the work traditionally done by law librarians and were positioned to do more as the benefits of desktop access became more apparent. How would the relationships between the two groups play out in their increasingly shared workplace? Were they separate professions or branches of a larger "information profession"? Were they professions at all?

Having little confidence in my own abilities to construct professional models for either librarians or technologists, I turned to the literature of the professions for help, and ended up relying heavily on the work of Andrew Abbott, a University of Chicago sociologist and author of The System of Professions: An Essay on the Division of Expert Labor, published in 1988. Although, by the time I wrote, Abbott's book was already too old to fully acknowledge the impacts of desktop computing and network communications on what he called "the information professions," 62 I found his classification of professions and his identification of "the information professions" as a group worthy of study to be particularly helpful to my project. Other writings on the profession of librarianship were also helpful. All are referenced in the article. ${ }^{63}$

For Abbott, all professions work in environments that are constantly changing with the emergence of new professional groups, the invention of 
new technologies, and the recognition of new political realities in the workplace. Within the workplace, professional groups compete for recognition through claims for jurisdiction over particular areas of work. ("Whose work is this?") Although some professions, such as law and medicine, assert claims of jurisdiction through licensing and regulation of who can perform the work, even they must compete with other groups for jurisdiction in the workplace. In a 1998 article dealing specifically with librarianship, Abbott wrote that "[p]rofessional work is usually work contested by other environing professions," and characterized the system of the professions as "a world of pushing and shoving, of contests won and lost." ${ }^{64}$ From this perspective, there are some areas in their work where doctors compete for jurisdiction with nurses and physician's assistants, lawyers compete with paralegals, and librarians with technologists. Librarians work with information itself as a discipline, and as a result they can find themselves competing for jurisdiction with professionals whose work is based on the knowledge of their discipline, which is held and organized by librarians. Donovan cites an example of this in a quotation from Fred Lerner's history of libraries, describing the early issue of who should select books for the collection: the librarian or the professor. ${ }^{65}$ Closer to home: who knows more about legal information: the law librarian or the law professor? ${ }^{66}$

Abbott also criticized the traditional "textbook sociology" approach to the study of the professions, which examined all knowledge-based occupations aspiring to professional status in light of the characteristics of law and medicine, then categorized those occupations as "semi-professions," perhaps at some stage of professionalization, moving toward being full professions like the two prototypes. ${ }^{67}$ (He notes as well that "the conceptual difference between profession and semi-profession probably has more to do with the difference between men and women than anything else." ${ }^{68}$ ) In opposition to the textbook approach, for Abbott, "[t]he professions all exist on one level," and "[w]hat really matters about an occupation-librarianship or any other-is its relation to the work that it does." 69 Abbott's approach is not in conflict with writers such as Talcott Parsons, who have defined the professions in terms of the characteristics of professional work (e.g., knowledge, skills or competencies, shared values) $;^{70}$ it is in conflict, however, with the idea that all professions must aspire to the things that characterize law and medicine, and distinguish them from other occupations.

Donovan's article does not acknowledge the kinds of distinctions among the professions employed by Abbott and others, arguing rather that, to be a profession, librarianship must be like law or medicine. As he puts it in 
discussing my article: "When [Danner] seeks to dissociate librarianship from the prototypical professions of law and medicine, he implicitly endorses the conclusion that librarianship is not a real profession." ${ }^{71}$ As a result, Donovan is unable to accept the premise that professional work can be based in service or in meeting the needs of library users as users define them. His own conclusion is that: "a professional does not necessarily render his own vision of the anticipated outcome to the library user. That task can only be a job."72 For Donovan, the concept of "service profession" is itself a contradiction: "The weak, user-based model that Danner succinctly describes invokes an external locus of control. Important decisions are made outside the librarian's sphere of influence." $" 73$ To Donovan, the idea denies librarians the autonomy necessary to the professional. He quotes the following passage from "Redefining a Profession" as a restatement of the weak model:

Librarianship developed as a service-oriented, client-centered profession: one in which meeting the client's needs as the client sees them was of more importance than the expertise of the professional. This perspective has differentiated librarianship from other professions, such as law or medicine. ${ }^{74}$

After the quotation, he states that this "conclusion instantiates the strain between two incompatible visions of librarianship as service occupation and information profession. This chimera, however, is unsustainable." ${ }^{, 75}$ Yet, the ideas that librarianship is a service profession, not merely an occupation, and that all professions need not emulate the characteristics of law and medicine are hardly original to "Redefining a Profession"; they are commonly accepted in the literature of the professions and the literature of librarianship. Abbott describes the information professions in terms of their roles in providing information to others: they "help clients overburdened with material from which thay [sic] cannot retrieve usable information.",76 Richard Mason has written that all information professionals are mediators, whose purpose is "to get the right information from the right source to the right client at the right time in the form most suitable for the use to which it is to be put and at a cost that is justified by its use." 77 Other writers, too, have emphasized the mission of librarianship highlighted in the Renaissance Committee. Unlike Donovan, they do not conclude that a professional culture of service, focused on meeting the needs of information seekers, deprofessionalizes librarianship. 


\section{CONCLUSION}

All professionals provide service to others using the particular knowledge and skills of their profession. In his book, Work and Integrity: The Crisis and Promise of Professionalism in America, William Sullivan cites the work of Eliot Freidson in support of the idea that professional work is "a model of good work ... a commitment to a body of knowledge and skill both for its own sake and for the use to which it is put." "78 Sullivan attributes the persistence of the professions in large part to the sense that professional work is intrinsically rewarding "in the ethical sense of contributing to the well-being of the society in which they work." 79

The service mission of law librarianship is to help those seeking legal information to find the information they need. Librarians have always used their skills to assist library users, not only to locate materials, but to formulate questions and strategies that will get them what they need. These are skills that may be increasingly important in the current time both to fulfill the needs of information seekers, and to support the values expressed by the Renaissance Committee and in other literature of the profession. Before ubiquitous access to information of all sorts via the web became commonplace, there was more convergence between the information seeker's need to find useful information and the library's traditional roles of acquiring, organizing, and preserving information, as well as providing access to it. Information-seeking took place within a context and space provided by the library, and each of the library's functions served the patron's needs, often in ways invisible to the user. In the print environment, Ranganathan's second law of library science: "Every reader his [or her] book" could not be implemented without implementing his other laws. ${ }^{80}$ In the digital environment, that may no longer be the case.

In considering how librarians should (and should have) responded to these threats to context, it is worth turning again to Terry Martin's comments at the 1996 AALL town meeting on the future of the profession. The systems failures that Martin noted as contributing to the need for intermediation between information seekers and information ("readers and their books") can be viewed as failures of the library profession. More than one writer has pointed out the detrimental effects of librarians' long-standing willingness to give up responsibility for building effective tools for locating information to publishers, and then to information technologists, and to be "mere tool-users" ourselves. ${ }^{81}$ Can we really defend the consistently baffling search options and displays of results provided by online public 
catalogs? Is it hard to understand why library users would prefer to insert undifferentiated terms into a search box, then to scan the results of the search to determine which will be most useful? Can we justify the costs of fully cataloging library holdings when we have not managed to convince our users that those efforts improve access to the materials they classify and describe? Perhaps, it is to these sorts of challenges that librarians should focus their attention.

Even as libraries change and as the resources they hold shift to new formats, which may themselves change some of the things that libraries do, the librarian's role of providing context for those seeking information remains essential to library users' abilities to successfully locate the information they need. ${ }^{82}$ In a recent article written to celebrate the addition of the one millionth volume to the collection of the University of Minnesota Law Library, an institution he describes as "a library in [the] grand manner," ${ }^{33}$ Bob Berring asked: "If law libraries can no longer be defined as buildings, and can no longer be viewed as synonymous with the collections of information that they contain, and are no longer the institutions that define legitimate information, then what is their true nature?" Not surprisingly, his answer was that "the soul of law libraries consists of law librarians." And he notes that this has always been so: law librarians "have long played the role of the intermediary between information and the person who needed it," and provided instruction to researchers both in locating information and in how to use it. ${ }^{84}$

Berring quotes a dean who remarked to him that he sees a great need: "We need to develop people who can stand between the information user and the information system. Someone who can understand user needs and translate complex systems." 85 Berring, of course, knows that it isn't necessary to develop or create such people; they already exist. It's not surprising, perhaps, that the dean misunderstands what librarians do. Perhaps he can be forgiven for not thinking that librarians might be the answer to the problem he poses; he is thinking of information-seeking in terms other than those involved in finding books in a library. But we ourselves cannot afford to link our professional identity too closely to traditional print-based library activities.

Twenty-five years ago, I published an article speculating on the future of legal reference service ${ }^{86}$ that concluded with a 1958 quotation from William R. (Bob) Roalfe, who developed the law libraries at Duke and at Northwestern and is well-known for his contributions to U.S. and international law librarianship. For me, as I think for Mike Chiorazzi, ${ }^{87}$ Roalfe has always been a particular professional hero. 
Writing then, I noted Roalfe's observation that the same complexities that created specialization in law library services would in future require even higher levels of service. Roalfe described the situation of the legal researcher then in terms still applicable (perhaps with a bit of tweaking) fifty years later:

[E]ven the specialist, let us say in antitrust law, or civil rights, or the person who must somehow locate particular items in that everexpanding mass of documentary publications, is often baffled by the array of materials in his own field, although he is thoroughly familiar with the substantive considerations involved. He often needs the help of one who, although not a specialist in the field, is familiar with the bibliographical problems involved. ${ }^{88}$

It is hard to imagine that meeting the legal information needs of the legal profession and the public is not at the core of what law librarians do. The ways we meet those needs may change along with the formats of the information with which we work, but the essence of our work remains grounded in a mission to connect those in need of information with the information they seek, and to provide the context that will help them understand and use what they find.

\section{NOTES}

1. He didn't. The second and final edition was published in 1967. I took his course in 1974 or 1975. Clarke also wrote biographies of the French librarian and scholar Gabriel Naudé, and the French Calvinist leader Henri de Rohan.

2. James M. Donovan, Skating on Thin Intermediation: Can Libraries Survive? LEGAL REFERENCE SERVICES Q., 2008, no. 2-3, at 95 [hereinafter Skating].

3. Including books: See LAW LIBRARIANSHIP IN THE TWENTY-FIRST CENTURY (Roy Balleste, Sonia Luna-Lamas, \& Lisa Smith-Butler, eds., 2007); THE CHANGING ROLE OF ACADEMIC LAW LIBRARIANSHIP: LEADING LIBRARIANS ON TEACHING LEGAL RESEARCH SKILlS, RESPONDING TO EMERGING TECHNOLOGIES, AND ADAPTING TO CHANGING TRENDS (2008).

4. Redefining the Law Librarian's Profession: A Town Meeting on the Future of Law Librarianship, July 22,1996, in TOWARD A RENAISSANCE IN LAW LIBRARIANSHIP 22, 27 (Richard A. Danner, ed., 1997) (comments of Harry S. (Terry) Martin).

5. Id. at 40 .

6. Toward a Renaissance in Law Librarianship: Report of the Special Committee on the Renaissance of Law Librarianship in the Information Age, in TOWARD A RENAISSANCE IN LAW LIBRARIANSHIP 3-18, supra note 4 [hereinafter Renaissance Report]. 
7. Richard A. Danner, Redefining a Profession, 90 LaW LiBR. J. 315 (1998) [hereinafter Redefining a Profession].

8. I will not comment at length on Donovan's comments/views about Harvard Law School's recent appointment of a vice dean for library and information resources without formal library training, and the decisions in recent years of several prominent law library directors to leave their positions and move to the faculty or to other administrative positions in their law schools. See Skating, supra note 2, at [107-111]. For Donovan, Harvard's appointment of a non-librarian to head the law library "detracts from efforts to advance the recognition of law librarianship as a profession." Id. at 108. Yet, it can be argued that the appointment's carrying with it a tenured place on the Harvard law faculty does just the opposite. See Palfrey Appointed as New Head of Harvard Law School Library (April 30, 2008), http://www.law.harvard.edu/news/2008/04/30_palfrey.php. As for the moves of several highly-regarded colleagues into other roles at their law schools, it is hard to imagine that any, when asked what is their profession, would say anything other than "law librarian" regardless of their current work. Each continues to contribute to the profession in a variety of ways. I am sympathetic to the general thrust of Donovan's comments regarding the role of library directors in the larger profession of law librarianship. Contrary to Donovan's view, I hope that most directors do not "hold their appointments because they have a specialized talent for bureaucratic management," Skating, supra note 2, at [109]; rather, I hope that it is for their leadership abilities within both their own institutions and the profession. Nor do I agree with his sense that the AALL Renaissance Committee report was "flawed" because of "a disproportionate representation of directors" on the committee stemming from "a belief that directors of institutions are necessarily better qualified to steer the profession than are its other members." Id. at [109-110]. I do think that over the last 10 years the demands on academic library directors resulting from rising costs, pressures to cede space to other law school programs, and the increasing need to defend and justify their own faculty status within their law schools have made it difficult for many directors to play as large a leadership role in the profession as they might, and perhaps in some cases have caused them to conflate their immediate issues as directors with those of the profession. The issues are not the same, and certainly the future of the profession is in the hands of all of its members; it does not depend on the actions of library directors.

9. For Donovan: "Librarians are important because libraries are irreplaceable." Skating, supra note 2, at [97].

10. Id. at [97]. See also id. at [102] ("[R]eady availability has altered how patrons view the universe of information-its organization and accessibility, and consequently their expectations toward all information providers, including libraries. Immersed as they are in an environment that promises them everything always, users do not necessarily understand why this is not an unqualified good.").

11. Id. at [97].

12. Id. at [107].

13. Id. at $[100]$.

14. Id. at [97].

15. See Laura B. Cohen, A Manifesto for Our Times, AM. LiBR., Aug. 2007, at 47,48 .

16. Id. at 49 . 
17. Id. at 47. For an interesting comparison of the technologies and other features of "Web 2.0" and "Web 1.0," see Graham Cormode \& Balachander Krishnamurthy, Key Differences between Web 1.0 and Web 2.0, FIRST MONDAY (June 2, 2008), http://www.uic.edu/htbin/cgiwrap/bin/ojs/index.php/fm/article/view/2125/1972.

18. Cohen, supra note 15 , at 48.

19. Skating, supra note 2, at [102].

20. Id. at [103].

21. Id. at [98].

22. Dave Muddiman, Towards a Postmodern Context for Information and Library Education, 17 EDUC. FOR INFO. 1, 16 (1999), quoted in Skating, supra note 2, at 98.

23. Muddiman, supra note 22, at 4.

24. Id. at 4.

25. Id. at $4-5$.

26. Id. at 5 .

27. Id. at 7.

28. Id. at 15 .

29. $I d$. at 16 (emphasis in original).

30. Nicholas Joint, Digital Libraries and the Future of the Library Profession, 56 LIBR. REV. 12 (2006).

31. Id. at 13 .

32. Id. at 14 .

33. Id. at 15 .

34. Id. at 17.

35. Id. at 20 .

36. Id. at 22 .

37. Skating, supra note 2, at [97].

38. Id. at [100].

39. Id. at [108].

40. Id. at [115].

41. Walt Crawford \& Michael Gordon, Future Libraries: Dreams, MadNESS, \& REALITY 3 (1995) quoted in Skating, supra note 2, at [14].

42. Skating, supra note 2, at [107].

43. Id. at 107.

44. See S. R. Ranganathan, Five Laws of Library Science (1931). For applications of Ranganathan's laws to law librarianship, see Morris L. Cohen: President's Page: Toward a Philosophy of Law Librarianship, 64 LAW LIBR. J. 1, 1 (1971) ("One could spend many hours pondering the implications of these brief aphorisms."); Richard A. Leiter, Reflections on Ranganathan's Five Laws of Library Science, 95 LAW LIBR. J. 411 (2003).

45. Skating, supra note 2, at [107].

46. Id. at [118].

47. Joint, supra note 30, at 22.

48. Skating, supra note 2, at [102].

49. Renaissance Report, supra note 6.

50. Id. at 3.

51. Redefining a Profession, supra note 7. 
52. Kathleen M. Carrick, Preface, in TOWARD A RENAISSANCE IN LAW LiBraRIANSHIP, supra note 4 , at v, v.

53. Renaissance Report, supra note 6, at 8-9.

54. Id. at 9. Reading these comments now, I can see their resonance with the remarks of Jack Clarke in my long-ago library school course at the University of Wisconsin.

55. Id. at 108. Donovan also suggests that the committee recommended expanding the definition of the term "law librarian" to include anyone, including nonprofessionals, "whose primary career is to work with legal information sources...." Skating, supra note 2, at [96], quoting Renaissance Report, supra note 6, at 14. This was not actually a recommendation of the committee, but rather an explanation of how the term "law librarian" would be used in the recommendations listed at the end of the report. Renaissance Report, supra note 6, at 14.

56. Skating, supra note 2, at [98].

57. Redefining a Profession, supra note 7, at 354. See also Kathleen Vanden Heuvel, Editorial, LEGAL REFERENCE SERVICES Q., no. 1-2, 1994, at 1, 3 (discussing librarianship as the basis for a new information field).

58. Skating, supra note 2, at [98].

59. See AALL Members Vote to Accept Proposed Bylaws Revisions, AALL SPECTRUM, Nov. 1999, at 2.

60. Bylaws of the American Association of Law Libraries Art. IV, §1.a.(1), in AALL DIRECTORY AND HANDBOOK 2007-2008 at 387 (47th ed., 2007).

61. See, e.g., Richard A. Danner, Facing the Millennium: Law Schools, Law Librarians, and Information Technology. 46 J. LEGAL EDUC. 43 (1996) (discussing an expanded administrative role for law librarians in light of law schools' increasing investments in technology).

62. ANDREW AbBotT, The System of PROFESSIONS: AN ESSAY ON THE DIVISION OF EXPERT LABOR 11 (1988) [hereinafter ABBOTT (1988)].

63. See, e.g., Richard O. Mason, What Is an Information Professional?, J. Educ. and Libr. Info. Sci., Fall 1990, at 122, 125; MiCHAEL F. WinTER, THE CULTURE AND CONTROL OF EXPERTISE: TOWARD A SOCIOLOGICAL UNDERSTANDING OF LIBRARIANSHIP 3 (1988).

64. Andrew Abbott, Professionalism and the Future of Librarianship, 46 LIBR. TRENDS 430, 433 (1998) [hereinafter Abbott (1998)].

65. Skating, supra note 2, at [118], quoting FrED LERNER: THE STORY OF LIBRARIES: FROM THE INVENTION OF WRITING TO THE COMPUTER AGE 186 (1998).

66. In introducing a 2008 American Association of Law Schools workshop for law librarians, John Garvey, dean of the Boston College Law School and president of the AALS, noted that as a young law professor he would never ask the help of law librarians-certainly, he knew more than they did about the law. Now, however, he said, he would not dream of not asking for a librarian's help in dealing with legal information. John H. Garvey, Welcoming Remarks at the AALS Workshop for Law Librarians, Cleveland, Onio (June 1, 2008).

67. Abbott (1998), supra note 64, at 431-432.

68. Id. at 431. On the influences of being considered a "woman's profession" on librarianship's professional culture, see Redefining a Profession, supra note 7 at 352 and sources cited therein. 
69. Abbott (1998), supra note 64, at 432.

70. See Talcott Parsons, Professions, in 12 InT'L ENCYClOPEDIA SoC. SCI. 536, 536 (1968).

71. Skating, supra note 2, at [100].

72. Id. at [101].

73. Id. at [100].

74. Redefining a Profession, supra note 7, at 352 (emphasis in the original), quoted in Skating, supra note 2, at [6].

75. Skating, supra note 2, at [7].

76. Аввотт (1988), supra note 62, at 216.

77. Mason, supra note 63, at 125.

78. William M. Sullivan, WORK AND InTEGRITY: THE CRISIS AND PROMISE OF Professionalism in AMERICA 14 (2d ed., 2005), quoting EliOT FreIDSON, ProfeSSIONALISM REBORN: THEORY, PROPHECY, AND POLICY 210 (1994).

79. $I d$. at 14 .

80. They are: "Books are for use"; "For every book, its reader"; Save the time of the reader"; "A library is a growing organism." See RANGANATHAN, supra note 44.

81. See Redefining a Profession, supra note 7, at 349-352 and sources cited therein.

82. See id. at 345 ("The ability to provide context to the client's process of information seeking will be key to the future of the information professions, but context is a product of both content and access, and can be provided only through consideration and understanding of both elements.").

83. Robert C. Berring, Deconstructing the Law Library: The Wisdom of Meredith Willson, 89 MINN. L. REV. 1381, 1406 (2005).

84. Id. at 1402 .

85. Id. at $1402-1403$.

86. Richard A. Danner, Reference Theory and the Future of Legal Reference Service, 76 LAW LIBR. J. 217 (1983).

87. See Michael G. Chiorazzi, William R. Roalfe: Builder of Libraries, Scholar, Association Animal, in Laura N. Gasaway \& Michael G. Chiorazzi, eds., LAW LIBRARIANSHIP: HISTORICAL PERSPECTIVES 215 (1996).

88. William R. Roalfe, Law Library Service from the Administrator's Point of View, 51 LAW LIBR. J. 349, 353-354 (1958), quoted in Danner, supra note 86, at 232. 